\title{
Halal Tourism in the Perspective of Indonesian Muslim Scholars: A Case Study in Magelang Regency
}

\author{
Agus Miswanto $^{1}$, M. Tohirin ${ }^{2}$ \\ \{agusmiswanto@ummgl.ac.id ${ }^{1}$ \} \\ Departement of Islamic Economic Law, Universitas Muhammadiyah Magelang, Indonesia ${ }^{1}$ \\ Doctoral student in Universitas Islam Negeri Sunan Kalijaga Yogyakarta ${ }^{1}$ \\ Departement of Islamic Education, Universitas Muhammadiyah Magelang, Indonesia²
}

\begin{abstract}
The issue of halal is an important requirement for a Muslim, including tourism. In Indonesia, there has been a discourse on halal tourism recently, because of the needs of the Muslim community who are known as the majority of the population in Indonesia. Therefore, this study tries to look at the perspectives of Indonesian Moslem scholars regarding this issue. This research is a descriptive-qualitative field research. The research method uses in-depth interviews to see their views on the issue. From the results of the research, it was found that $55.6 \%$ of the scholars agreed with the regulation of halal tourism, because this would improve the economy of the people $(55.6 \%)$ and was the guidance of Islamic law (55.6\%). When asked about matters related to halal tourism, the scholars revealed 3 things, namely tourist destinations, culinary spots, and lodging (hotels). Regarding the Borobudur temple, the scholars disagree (44.4\%) on making it as a halal tourist destination, because the place does not belong to Muslims, but is a legacy of Buddhist civilization.
\end{abstract}

Keywords: Halal tourism, Indonesian ulama, Islamic law

\section{Introduction}

Every human being who has a belief and a religion will find a foundation in his life with what is his religious belief. Likewise, a Muslim will base all aspects of his life on his religion. In the life dimension of a Muslim, a very basic issue is understanding what is allowed and what is prohibited. Therefore, the issue of halal and haram is an important issue in the life of Muslims wherever they are.

Tourism is actually a part of human culture. So that human life cannot be separated from tourism. Human mobility due to tourism has improved the economic life of the community, thus having an impact on welfare. Halal tourism is a tourism business that is in line with sharia regulations, which are expected to attract tourists to visit. It's just that, as Indonesia as the largest Muslim country in the world, the development of halal tourism has not shown significant progress. Based on data from 2018, the main tourist destinations for Muslims are Turkey, United Arab Emirates (UAE), France, Russia, and Malaysia [1]. And Indonesia, as the country with the largest Muslim population, has not become the main destination for visits by world Muslim tourists. Even though all the tourism potential of this nation is very rich and diverse. Therefore, structured, well-planned strategies and policies are very important for tourism development. 
Ulama as the front guard in understanding Islam have an important role in encouraging good policies for the development of the ummah, including the economy-tourism and the halal cultural values of society. In this study, the author tries to see about the perspectives of the scholars who are members of the Indonesian Ulama Council of Magelang Regency regarding halal tourism policy. The research results are expected to contribute to the development of halal tourism in Indonesia, especially the Magelang region.

\section{Method}

This research is a descriptive qualitative analysis. The data collection method used in-depth interviews. The object of research is the perspective of the ulama who are members of the Indonesian Ulama Council, Magelang Regency. So that the research subjects are scholars at the institution. To analyze the data, researchers used the deductive-inductive method. In order to comprehensively understand the thoughts and opinions of the scholars, the researcher uses the theory of discourse analysis, so that the opinions and thoughts of the scholars can be known in the context of the constellation of debate about halal tourism that resonates in Indonesia today.

\section{Results and Discussion}

\subsection{Results}

The Indonesian Ulema Council (MUI) of Magelang Regency is part of the Indonesian Ulema Council at the Center, in Jakarta. The management of the MUI from the central to regional levels reflects the elements of representation of various Islamic community organizations in Indonesia. Usually, representatives of NU and Muhammadiyah are the dominant organizational part of the MUI management structure. This is because these two organizations are the largest organizations in Indonesia, so they dominate this organization. MUI was formed in 1975, with its first chairman being Prof. DR Buya Hamka. [2] The establishment of MUI in various regions was actually earlier than the formation of the central MUI, even the formation of the central MUI was the result of the declarations of 26 regional MUI representatives at that time [2]. The contribution of MUI in the religious context in Indonesia from time to time continues to increase, even the fatwas issued have an impact on social and political life. Therefore, the opinions of the MUI on various matters in relation to Islamic religious life have an important meaning in the context of the Indonesian nationality.

In the regional context, the role of MUI is institutionalized in the regional MUI management. In Magelang district, the management of MUI is also from various elements of Islamic mass organizations which are reflected in the MUI organizational structure. MUI Magelang Regency has several parts of the organizational structure, namely the daily board, the fatwa commission, the Education and Da'wah commission, the commission for empowering families and children, the anti-alcohol and drug movement (GANAS-ANAR), and the Muallaf center. In 2020-2024, there are around 30 administrators of MUI Magelang Regency. In this study, from about 30 MUI administrators in Magelang regency, there were about 9 people who could be interviewed regarding the issue of halal tourism [10].

In this study, there were four questions asked of the scholars regarding the issue of halal tourism. The four questions are as follows, namely: Is halal tourism included in the guidance of 
sharia? Why do you need regulations related to halal tourism? If Borobudur is used as a halal tourist destination? and are there any benefits in developing halal tourism?

Related to the idea of halal tourism. The researcher asked the scholars a question, namely, does halal tourism have Sharia guidance? Answering this question, which all scholars express that the idea of halal tourism has a footing in the Sharia. Of that total, of which $55.6 \%$ of respondents stated agreed, while $44.4 \%$ strongly agreed. From this statement, it provides an explanation that in Islamic law there are guidelines related to the development of halal tourism. Even the scholars stated that the scope of halal tourism is not only limited to tourist attractions, but also related to culinary and lodging.

Regarding regulations related to halal tourism, $44.4 \%$ of the scholars thought that regulation was necessary, while $55.6 \%$ stated that regulation was needed. With the existence of regulations, the development of halal tourism can be planned and carried out properly by the government. Without regulations, the development of halal tourism is only random, people are only groping without a definite direction. So that the development of halal tourism does not provide certainty of significant results and impacts. Therefore, policies that are set forth in the form of regulations both from the central and regional levels, can provide clear directions for both the government and the community in developing halal tourism.

Regarding Borobudur being used as a halal tourist destination, the scholars have a variety of opinions, $33.3 \%$ agree, $22.2 \%$ strongly agree, $33.3 \%$ say neutrality, and $11.1 \%$ disagree. The plurality of opinions is because Borobudur is a relic of Buddhist civilization. And the scholars who agree and strongly agree, actually do not see the site being used as a tourist destination, but the surrounding communities who have been involved in preserving this cultural heritage are Muslims. Thus, businesses that grow around sites managed by Muslims are developed to become centers of halal tourist destinations, both regarding culinary businesses, lodging (hotels), and others. Meanwhile, those who have a neutral opinion and disagree (44.4\%) regarding Borobudur being made a halal tourist destination, they are of the opinion that Borobudur temple is a cultural heritage and a place of Buddhist worship. Therefore, Borobudur should not be used as a halal tourist destination. Because the term halal is very Islamic, so it should not be associated with other religious sites outside of Islam. It's just that scholars who have a neutral and disagreeable opinion have the same opinion regarding the development of halal tourism that is outside the temple sites managed by Muslims.

And regarding the benefits of developing halal tourism, $55.6 \%$ of the scholars think that they are very supportive and strongly agree that the development of halal tourism will provide an increase in economic welfare for the Muslim community. Meanwhile, 22.2\% stated that the development of halal tourism does not necessarily increase the economic welfare of the community. Increasing economic welfare is related to good management so that it attracts interest and attracts tourists to tourist sites. If the development of halal tourism increases the capacity of the community to be able to develop and attract tourists because of its uniqueness and excellence, it will have an impact on the community's economy.

\subsection{Discussion}

\subsubsection{Halal tourism concept}

The term halal tourism is actually a relatively new term in the context of tourism. The term halal was originally used in the context of the food industry, then this term is used for tourism whose purpose is to provide service facilities for Muslim tourists in accordance with the guidelines and teachings of Islamic law [1]. Yhe idea of halal tourism was triggered by Islamic 
conference countries with various terms, namely halal travel, Islamic Tourism, Muslim friendly tourism, halal hospitality [1]. In the Indonesian context, halal tourism is elaborated in terms of sharia tourism. Halal tourism places religious values as the basis for developing tourism services. According to Lubis, sharia tourism is an activity that is supported by various facilities and services provided by the community, businessmen, government and local governments that comply with sharia provisions [3].

Halal tourism can be developed in four areas, namely location, by combining Islamic values in tourist locations; second, travel services with the expectation of a travel standard that is friendly to the Shari'a, such as non-ikhtilath, travel by paying attention to prayer times; third, culinary with respect to halal food standards for tourists; fourth, lodging, all services and facilities by implementing sharia hotel standards [4]. Meanwhile, Satriana and Faridah put forward 14 main principles or requirements for halal tourism, namely: 1) Halal food; 2) No liquor (containing alcohol); 3) Not serving pork products; 4) There is no discotheque; 5) Male staff for male guests, and female staff for female guests; 6) Suitable entertainment; 7) Facilities for gender-separated prayer rooms (mosques or mushalla); 8) Islamic clothing for staff uniforms; 9) Availability of Al-Quran and prayer equipment in the room; 10) Qibla directions; 11) Art that does not describe the human form; 12) The toilet is positioned not facing the Qibla; 13) Islamic finance; and 14) Hotels or other tourism companies must follow the principles of zakat [5].

\subsubsection{Halal tourism regulations}

Until now, regulations regarding halal tourism business activities are still unclear. At the national level, the ministry once issued several regulations on halal tourism, but these were later repealed. In 2014, for example, the Ministry of Tourism and Creative Economy issued Ministerial Regulation Number 2 of 2014 concerning Guidelines for Implementing Sharia Hotel Businesses. However, in 2016, Ministerial Regulation No. 2/2014 concerning Guidelines for the Implementation of Sharia Hotel Businesses is revoked by the Minister of Tourism Regulation No.11 of 2016 because it is deemed no longer in accordance with the demands and developments of tourism today. In addition, the Minister of Tourism has also issued Regulation Number 1 of 2016 concerning the Implementation of Tourism Business Certification. This regulation regulates halal tourism business certification. However, the article regarding halal tourism business certification in this regulation was also revoked with the issuance of the Minister of Tourism of the Republic of Indonesia Regulation Number 12 of 2016 concerning Amendments to the Regulation of the Minister of Tourism Number 1 of 2016 concerning the Implementation of Tourism Business Certification.

With the revocation of several Ministerial regulations above, there are practically no more regulations governing halal tourism. And with the repeal of several existing regulations, it seems that the central government is still ambiguous in developing halal tourism in Indonesia. Halal Tourism Arrangements can be made in the form of regional regulations (Perda) or Governor Regulations (Pergub), it seems like this is the case in West Nusa Tenggara (NTB), [6] but it can only be done for local governments that are concerned about halal tourism and these regulations only local in nature so that it cannot be used as a national reference.

In 2016, the National Sharia Council-Indonesian Ulema Council (DSN-MUI) issued Fatwa Number 108 / DSN-MUI / X / 2016 concerning Guidelines for Implementation of Tourism Based on Sharia. The tourism aspects that are regulated in it include: hotels, spas, saunas and massages, tourist attractions, and travel agencies. This fatwa from the DSN-MUI will have no impact, if it is not implemented by the government in the form of laws and other regulations. 
Therefore, if the government has the will to develop halal tourism, then the government must have a clear policy as outlined in this set of rules governing halal tourism. So, halal tourism in Indonesia will experience an increase and acceleration.

\subsubsection{Borobudur as a halal tourist destination?}

Regarding Borobudur to be developed as a halal tourist destination, in fact until now there has not been any policy from the government, either the regional government or the central government. Likewise, the people in the area around the Borobudur Temple have also not had any discourses and initiatives for the development of halal tourism in the area.

The development of halal tourism is not only related to the location of the main destination, but also to other things outside of it, such as culinary, lodging, and travel services. Regarding Borobudur, as a halal tourist destination, it is theologically impossible, because Borobudur is a cultural heritage of Buddhism, and is still used for the annual celebration of Indonesian Buddhists and even the world. In this context, the scholars are aware and highly respect that Borobudur temple is an important part of Buddhist life, even though culturally it has become an important part of the Indonesian heritage. Therefore, the development of halal tourism can be carried out in three main contexts, namely culinary, lodging, and travel services (transportation). And these three sectors, generally those who are working on it are Muslims. Lodging and culinary around the Borobudur area are Muslims. And in the context of tourist visits, generally tourists who come to visit Borobudur are Muslims from various regions in Indonesia. Therefore, culinary, lodging and transportation needs are actually related to the people who visit, if they are provided with services in accordance with the rules of the Sharia, it will have an impact on satisfaction and also peace of mind.

\subsubsection{Halal tourism benefits}

Indonesia is known as the largest Muslim-majority country in the world. Regarding the development of halal tourism, Indonesia should be able to become the main destination for world halal tourism destinations. Unfortunately the development of halal tourism in Indonesia is still far behind compared to other Islamic countries, such as Turkey, Malaysia, and United Arab Emirates (UAE) [1]. So that these three countries become the world's main halal tourist destinations today. And these three countries get the usual benefits from tourist visits from various countries from the Middle East region and others. Economically and in terms of income, these three countries have benefited from developing their halal tourism, so that they can attract tourists to their countries.

In the Indonesian context, the development of halal tourism has actually started. It's just that the development is rather slow compared to other Islamic countries. Areas in Indonesia that are trying to develop halal tourism include West Nusa Tenggara, [6] West Sumatra, [7] and Aceh [8]. To date, the province of West Nusa Tenggara has been quite successful in promoting its region to foreign countries, and in attracting foreign tourists to the area [9]. Therefore, these areas can become examples for the development of halal tourism in Indonesia. For the context of Magelang, the development of halal tourism has strategic opportunities, because Magelang has interesting tourist attractions besides Borobudur temple. 


\section{Conclusion}

From the above discussion, it can be concluded that halal tourism in Sharia is indeed guided. In the context of halal tourism, there are four things that need to be developed, namely tourist attractions as the main destination, culinary, namely services for the consumption needs of tourists, lodging, namely places of rest that tourists need to unwind, and travel services (transportation). These four things, when you get a touch of sharia values, will have an impact on tourist service satisfaction, especially for Muslim tourists.

The development of Borobudur as a halal tourist destination is still unclear. The scholars have not agreed, because of respect for Buddhists who use Borobudur Temple as a place of worship and celebration. The development of halal tourism in the context of Borobudur, only in the context of tourism services such as culinary, lodging and transportation. Because these three things are related to services related to Muslims.

The scholars are of the view that halal tourism has a positive impact on improving the economy of the people. The economic benefits of halal tourism have been proven by several countries which have become the center of world halal tourism destinations. Until now, the direction of halal tourism policy in Indonesia has not been clear, it's just that several areas are trying to develop such as West Nusa Tenggara, West Sumatra and Aceh.

\section{Acknowledgement}

The author especially thanks to the Rector of Universitas Muhammadiyah Magelang, the committee of the 2nd Borobudur International Symposium, reviewers and proofreaders, who help and support to publish this article.

\section{References}

[1] A. R. Subarkah, J. B. Rachman, and Akim, "Destination Branding Indonesia Sebagai Destinasi Wisata Halal,” J. Kepariwisataan Destin. Hosp. dan Perjalanan, vol. 4, no. 2, pp. 84-97, 2020.

[2] M. A. N. Sholeh, Metodologi Penetapan Fatwa majelis Ulama Indonesia, 1st ed. Jakarta: Emir Penerbit Erlangga, 2016.

[3] M. Z. M. Lubis, "Prospek destinasi wisata halal berbasis ovop (one village one product)," J. Kaji. Ekon. Islam, vol. 3, no. 1, pp. 30-47, 2018.

[4] F. Ramadhany and A. A. Ridlwan, "Implikasi Paraiwisata Syariah Terhadap Peningkatan Pendapatan dan Kesejahteraan Masyarakat," Muslim Herit., vol. 3, no. 1, pp. 147-164, 2018.

[5] E. D. Satriana and H. D. Faridah, "Halal Tourism: Development, Chance and Challenge," J. Halal Prod. Res., vol. 1, no. 2, p. 32, 2018.

[6] A. M. Fahham, "Tantangan Pengembangan Wisata halal di Nusa Tenggara Barat (The Challenge of Developing Halal Tourism in Nusa Tenggara Barat)," Aspirasi, vol. 8, no. 1, pp. 65-79, 2017.

[7] Rozalinda, Nurhasanah, and S. Ramadhan, "Industri Wisata Halal di Sumatera Barat: Potensi, Peluang dan Tantangan," Maqdis J. Kaji. Ekon. Islam, vol. 4, no. 1, pp. 45-56, 2019.

[8] Muis, "Perkembangan Peluang dan Tantangan Wisata Halal di Aceh," Adabiya, vol. 22, no. 1, pp. 41-55, 2020.

[9] A. R. Subarkah, "Diplomasi pariwisata halal nusa tenggara barat," Intermestic, vol. 2, no. 2, pp. 188203, 2018. 
[10] Fibrianti, N. (2020). Penyelenggaraan Perlindungan Konsumen: Sinergi Negara, Pelaku Usaha dan Konsumen. Borobudur Law Review, 2(2), 90-101. 